\title{
CLINICAL EVALUATION OF PATIENTS UNDERGOING DYNAMIC PEDICLE FIXATION IN LUMBAR SPINE
}

\author{
AVALIAÇÃO CLÍNICA DE PACIENTES SUBMETIDOS À FIXAÇÃO PEDICULAR DINÂMICA \\ NA COLUNA LOMBAR
}

\author{
EVALUACIÓN CLÍNICA EN PACIENTES SOMETIDOS A FIJACIÓN PEDICULAR \\ DINÁMICA DE LA COLUMNA LUMBAR
}

Felipe José Vieira Figueiredo¹, Paulo Roberto Brum², Rogério Frota Góes Monteiro²

\begin{abstract}
Objective: To evaluate the preliminary clinical results and complications in patients undergoing dynamic pedicle fixation of the spine in the treatment of a specific group of degenerative lumbar disease. Methods: In this preliminary retrospective study, we selected 14 patients who underwent surgery from January 2006 to July 2010. We selected only patients with spondylolisthesis without spondylolysis (Grade 1 Meyerding). All patients underwent surgery at one level and the levels mostly addressed were: L3-L4, L4-L5 or L5-S1. The approach was the same in all patients (posterior median approach with preservation of the posterior elements). All patients underwent intense conservative treatment without clinical response and the same research algorithm preoperatively. Results: Retrospective analysis of Oswestry questionnaire after selection and publication of results of 14 patients with Grade 1 spondylolisthesis who underwent dynamic pedicle stabilization in a total of 56 pedicle screws, being all in one level. There was no fracture of any screws, the mean hospital stay was a day and a half, no patient required blood transfusion and there were no cases of infection, with significant improvement in the Oswestry questionnaire. Conclusion: In this study, the dynamic pedicle stabilization method proved to be an excellent treatment option when surgical criteria are strictly adhered to. There was an improvement in Oswestry values, lower hospital stay and low rate of complications, consisting of an alternative in motion preservation surgery.
\end{abstract}

Keywords: Spine; Low back pain; Arthrodesis.

\begin{abstract}
RESUMO
Objetivo: Avaliar os resultados clínicos preliminares e as complicações em pacientes submetidos à fixação pedicular dinâmica da coluna no tratamento de um grupo específico portador de doença lombar degenerativa. Métodos: Neste estudo retrospectivo preliminar, foram selecionados 14 pacientes submetidos à cirurgia no período de janeiro de 2006 a julho de 2010. Foram selecionados apenas os pacientes com espondilolistese sem espondilólise (Grau 1 de Meyerding). Todos os pacientes foram submetidos à cirurgia em um nível e os níveis abordados foram, em sua maioria, L3-L4, L4-L5 ou L5-S1. A via de acesso foi a mesma em todos os pacientes (via mediana posterior com preservação dos elementos posteriores). Todos os pacientes foram submetidos a intenso tratamento conservador sem resposta clínica e ao mesmo algoritmo de investigação no pré-operatório. Resultados: Análise retrospectiva do questionário Oswestry, após seleção e publicação de resultados dos 14 pacientes com espondilolistese Grau 1 submetidos à cirurgia de estabilização pedicular dinâmica, em um total de 56 parafusos pediculares, sendo todos em um nível. Não se observou quebra de nenhum parafuso, o tempo médio de internação foi um dia e meio, nenhum paciente necessitou de transfusão sanguínea e não houve nenhum caso de infecção, com melhora significativa do questionário Oswestry. Conclusão: Nesse estudo o método de estabilização pedicular dinâmica demonstrou ser uma excelente opção de tratamento quando os critérios de indicação cirúrgica são rigorosamente respeitados. Observou-se melhora nos valores de Oswestry, baixo tempo de internação hospitalar e baixo índice de complicação, consistindo em alternativa na cirurgia de presenvação do movimento.
\end{abstract}

Descritores: Coluna vertebral; Dor lombar; Artrodese.

\section{RESUMEN}

Objetivo: Evaluar los resultados clínicos preliminares y las complicaciones en pacientes sometidos a fijación pedicular dinámica de la columna vertebral en el tratamiento de un grupo específico con enfermedad lumbar degenerativa. Métodos: En este estudio retrospectivo preliminar, se seleccionaron 14 pacientes que se sometieron a la cirugía de enero de 2006 a julio de 2010. Solamente los pacientes con espondilolistesis sin espondilolisis (Grado 1 Meyerding) fueron seleccionados. Todos los pacientes fueron sometidos a cirugía de un único nivel y los niveles cubiertos fueron en su mayoría L3-L4, L4-L5 o L5-S1. La vía de acceso fue la misma en todos los pacientes (mediana posterior con la preservación de los elementos posteriores). Todos los pacientes fueron sometidos a un intenso tratamiento conservador sin respuesta clínica y el mismo algoritmo de la investigación antes de la operación. Resultados: El análisis retrospectivo del cuestionario Oswestry después de la selección y publicación de los resultados de 14 pacientes con espondilolistesis de Grado 1 que se sometieron a cirugía de estabilización pedicular dinámica en un total de 56 tornillos pediculares, siendo todos en un solo nivel. No hubo fractura de los tornillos, la estancia media hospitalaria fue de un día y medio, ningún paciente requirió transfusión de sangre y no hubo casos de infección, con una mejora significativa en el cuestionario de Oswestry. Conclusión: En este estudio el método de estabilización pedicular dinámica resultó ser una excelente opción de tratamiento cuando los criterios de indicación se cumplan estrictamente. Hubo una mejora en los valores de Oswestry, bajo tiempo de estancia hospitalaria y menor tasa de complicaciones, siendo una alternativa a la cirugía de conservación del movimiento.

Descriptores: Columna vertebral; Dolor de la región lumbar; Artrodesis.

1. Clinica da Coluna do Dr. Paulo Roberto Brum, Petrópolis, RJ, Brazil.

2. Hospital SantaTeresa, Petropolis, RJ, Brasil.

Study conducted at Clinica de Coluna do Dr. Paulo Roberto Brum; Hospital Santa Teresa e Hospital de Beneficiência Portuguesa, Petrópolis, RJ, Brazil.

Correspondence: Rua Real Grandeza 139, sala 601. Botafogo. Rio de Janeiro, RJ, Brazil. 22281-033. felipeortopedia@gmail.com 


\section{INTRODUCTION}

Spinal fusion (vertebral arthrodesis) is the treatment of choice for lumbar instability, but entails mechanical stress at the levels adjacent to the fusion. Surgeries that preserve mobility, including posterior dynamic pedicle fixation, have attracted the interest of many spinal surgeons, because they prevent the consequences of spinal fusion. ${ }^{1-3}$

Dynamic stabilization systems allow restricted motion through the functional spinal unit. These principles have been described by Mulholland, Sengupta apud Bertagnoli et al., ${ }^{4}$ Stoll et al. ${ }^{5}$ and Dubois et al., ${ }^{6}$ who believe that these systems act by restricting the zone of movement to a near-normal range in which the load on the lumbar spine can be better distributed. They also believe that this system can distribute the load on the spine better, due to the balance that occurs after its insertion. ${ }^{5-8}$ This system was also designed to preserve kinematics between the segments, and to improve load distribution between facet joints. ${ }^{7-10}$ The system is also designed to minimize adjacent disc disease, in the case of surgery to more than two intervertebral levels. ${ }^{10-13}$

Dynamic pedicle devices began with Graf ${ }^{13,14}$ who invented the Graf ligament system. ${ }^{14}$ Despite having been widely used, there is no good quality study on this material, and recent studies, such as the one by Rigby et al. ${ }^{15}$ advise against the use of this system.

Our study uses a system called Dynesys (Zimmer), which has a different proposal, as it attempts to control both flexion and extension. It consists of a tension band with an elastic spacer. In flexion, there is a cord (Polyethylene-Terephthalate) which acts as a tension band, controlling this movement and in extension, elastic spacers (Urethane-Polycarbonate) act by restricting the range of this motion ${ }^{8}$ (Figure 1).

In other published articles, Schnake et al. ${ }^{9}$ evaluated a series of 26 patients diagnosed with spinal stenosis and neurogenic claudication. They used the decompression technique associated with the Dynesys dynamic stabilization method. The technique achieved $87.5 \%$ therapeutic success, but $17 \%$ of lucency across the surgical material. However, all patients are asymptomatic.

Stoll et al. ${ }^{5}$ conducted a prospective multicenter study to assess the efficacy and safety of Dynesys in the treatment of several lumbar spine pathologies. The study involved the assessment and performance of surgery on 83 patients with the following pathologies: (60.2\%) spinal stenosis $(24.1 \%)$ disc degeneration (8.4\%) disc herniation and (6\%) review of spinal surgery. The follow-up period was 38 months. This study showed the results for pain improvement and reoperation rates that were comparable to those of fusion techniques.

The aim of our study was to assess the preliminary results of surgical treatment using the dynamic transpedicular fixation technique in patients with Grade 1 degenerative spondylolisthesis without associated spinal spondylolysis.

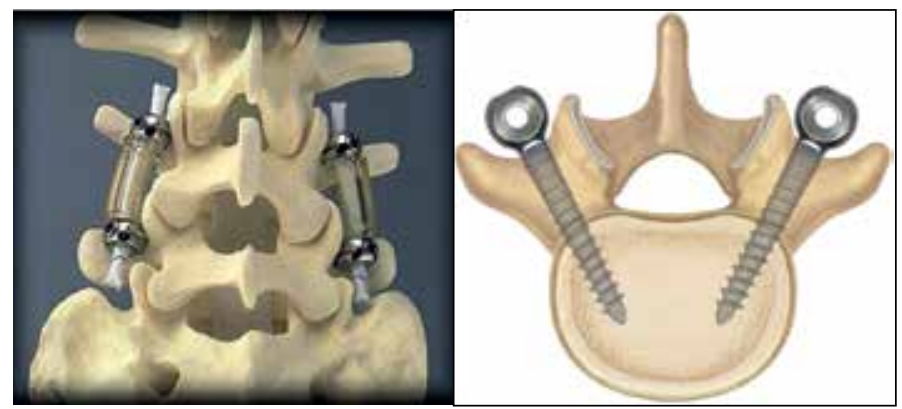

Figure 1. Posterior pedicle fixation system.

\section{MATERIALS E METHODS}

The study involved patients diagnosed with degenerative spondylolisthesis (Grade 1), who underwent surgical treatment via posterior approach with muscle and ligament preservation of the posterior elements. (Figure 2) Patients underwent surgery between January 2006 and June 2010. Patients undergoing surgery for the following

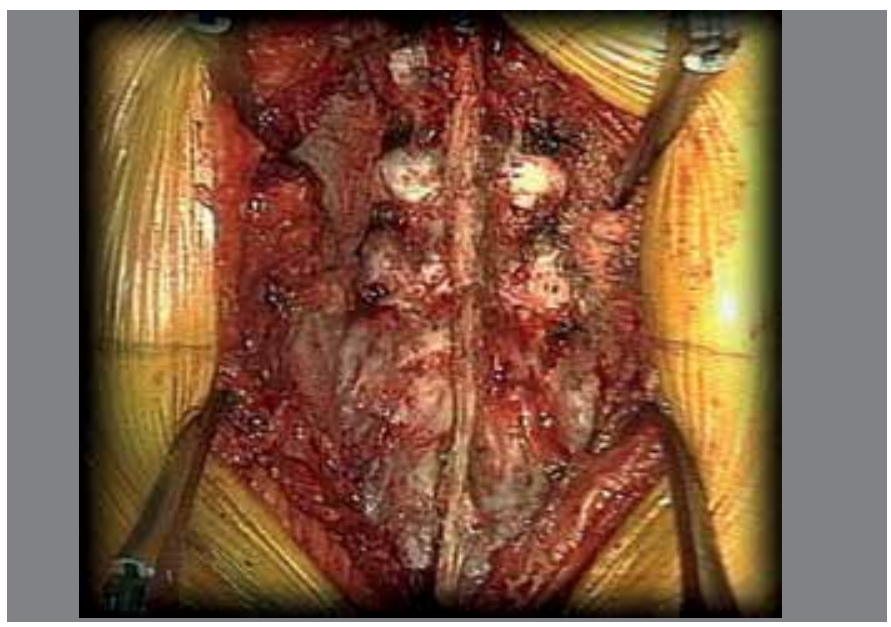

Figure 2. Dynesys System - preservations of posterior elements.

conditions were excluded from this study: degenerative disc disease, grade 2 spondylolisthesis, severe central stenosis, adjacent disc disease, and surgery to two or more levels. The patients gave their consent to participate in the study by signing an Informed Consent Form, and the study was approved under protocol number 01/2011, by the Spine Clinic of Dr. Paulo Roberto Brum, Petropolis, RJ, Brazil.

All the patients were operated on by the same spine team of Professor Doctor Paulo Roberto Brum. The implants used were of the Dynesys System ${ }^{\circledR}$ (Zimmer, USA), using the technique described, with preservation of the posterior stabilizing elements, without violating the joint facets, and pedicle fixation via the posterior median approach. Early mobilization was allowed in the postoperative period, with the insertion of a submuscular drain that was removed on the first day after surgery. All the patients had less than $150 \mathrm{~mL}$ of drainage during the first 24 postoperative hours, upon removal of the drain. The clinical parameters evaluated were: age, gender, and the occurrence of complications, such as infection and bleeding or failure of the implant and length of hospital stay. The Oswestry questionnaire was applied to assess quality of life, health and functional capacity before surgery and one year after surgery.

The radiographic evaluation included: Checking the anatomical location of the pedicle screws, changes in the degree of looseness of the implant and any sign of radiolucency around the pedicle screws. (Figure 3)

The data analysis was obtained with the help of Excel software using the student t-test, obtaining a paired statistical analysis in the periods described, comparing Oswestry values in the pre- and operative periods.

The overall average of the results obtained was calculated to demonstrate the general variation of the mean of the questionnaire.

\section{RESULTS}

Five male patients (35.71\%) and nine female patients (64.29\%) (Table 1) with ages ranging from 39 to 65 years were included in the study. All patients underwent surgical treatment via posterior median approach. Two patients were treated at level L3/L4 (14.28\%), nine patients were treated at level L4/L5 (64.28\%), and three were treated at level L5/S1 (21.42\%).

Grade 1 degenerative spondylolisthesis was the disease chosen in this study, while any other cause associated with this spondylolisthesis was excluded from the study. No cases of infection were observed, and no reoperations were carried out in the selected group.

The evaluation of the Oswestry questionnaire revealed a mean percentage of $53.75 \%$ in the preoperative period and of $11.80 \%$ in the postoperative period, with $p$-value $<0.0001 .85 .71 \%$ of patients exhibited intense disability or greater in the preoperative period, and $92.85 \%$ of patients exhibited minimum disability in the pos operative period. (Table 1) 


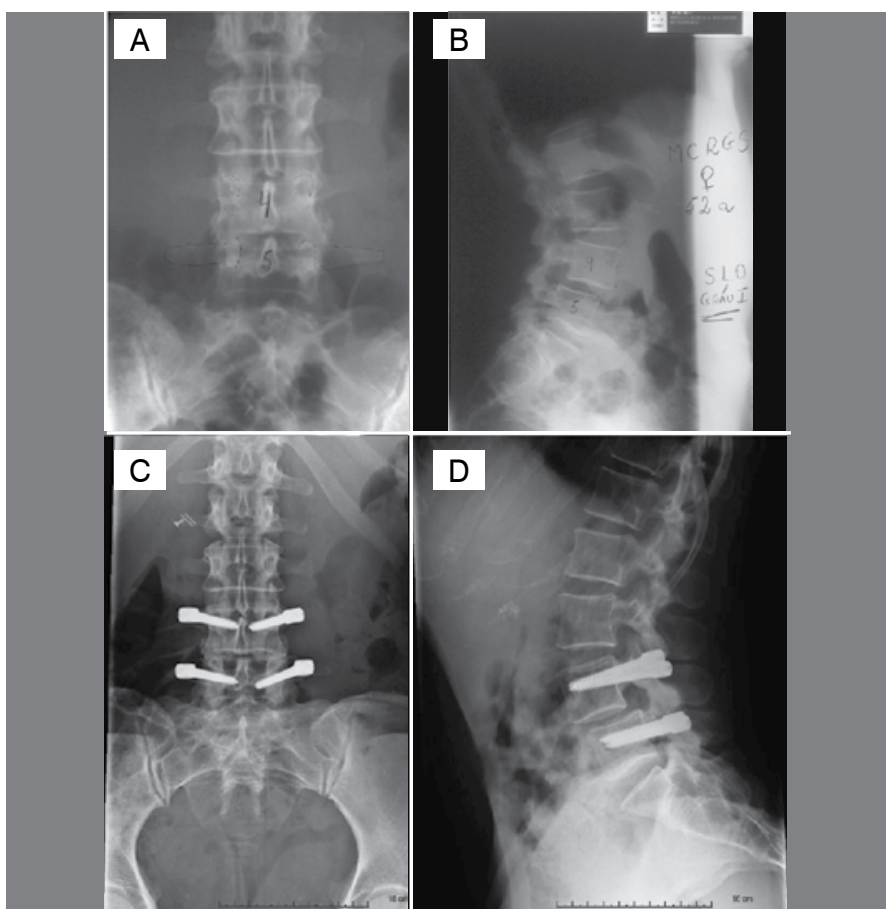

Figure 3. Patients with degenerative spondylolisthesis at L4/L5. (A) Lateral View. (B) AP View. (C) View 1 year after surgery. (D) AP 1 year after surgery.

The radiographic analysis revealed no change in the positioning of the pedicle screws in the review consultation, and no sign of loosening or radiolucency around the pedicle screws at the one-year review consultation, in which the clinical interrogation was carried out. There was no loss of sampling in this analysis, but if we were to use a two-year period, the group would be reduced to 12 patients, and for a three-year period, it would be reduced to nine patients.

\section{DISCUSSION}

Pedicle stabilization via the dynamic posterior approach using the Dynesys system is indicated for these pathological mobile segments. ${ }^{9-13}$ The principle of dynamic stabilization is to return the treated segment to the range of physiological mobilization, acting on segmental motor dyskinesia. This study was conducted retrospectively with a small sub-group treated for Grade 1 degenerative spondylolisthesis. The choice of this study group was based on the
Table 1. Age, treated levels pre- and postoperative clinical evaluation.

\begin{tabular}{c|c|c|c|c|c}
\hline Patients & Sex & Age & Level & Oswestry pre- & Oswestry post- \\
\hline 01 & $\mathrm{~F}$ & 65 & $\mathrm{~L} 4 / \mathrm{L} 5$ & $71.10 \%$ & $28.90 \%$ \\
\hline 02 & $\mathrm{~F}$ & 55 & $\mathrm{~L} 5 / \mathrm{S} 1$ & $44.40 \%$ & $8.90 \%$ \\
\hline 03 & $\mathrm{M}$ & 52 & $\mathrm{~L} 4 / \mathrm{L} 5$ & $28.90 \%$ & $6.70 \%$ \\
\hline 04 & $\mathrm{~F}$ & 59 & $\mathrm{~L} 4 / \mathrm{L} 5$ & $70.70 \%$ & $11.00 \%$ \\
\hline 05 & $\mathrm{~F}$ & 48 & $\mathrm{~L} 4 / \mathrm{L} 5$ & $35.00 \%$ & $12.00 \%$ \\
\hline 06 & $\mathrm{~F}$ & 53 & $\mathrm{~L} 4 / \mathrm{L} 5$ & $67.50 \%$ & $16.50 \%$ \\
\hline 07 & $\mathrm{M}$ & 53 & $\mathrm{~L} 5 / \mathrm{S} 1$ & $58.70 \%$ & $13.81 \%$ \\
\hline 08 & $\mathrm{~F}$ & 52 & $\mathrm{~L} 4 / \mathrm{L} 5$ & $49.50 \%$ & $9.55 \%$ \\
\hline 09 & $\mathrm{~F}$ & 58 & $\mathrm{~L} 5 / \mathrm{S} 1$ & $61.30 \%$ & $9.80 \%$ \\
\hline 10 & $\mathrm{M}$ & 39 & $\mathrm{~L} 4 / \mathrm{L} 5$ & $58.00 \%$ & $13.20 \%$ \\
\hline 11 & $\mathrm{~F}$ & 46 & L4/L5 & $53.13 \%$ & $14.20 \%$ \\
\hline 12 & $\mathrm{M}$ & 51 & L3/L4 & $49.56 \%$ & $5.20 \%$ \\
\hline 13 & $\mathrm{M}$ & 54 & L3/L4 & $55.50 \%$ & $7.50 \%$ \\
\hline 14 & $\mathrm{~F}$ & 61 & L4/L5 & $49.23 \%$ & $7.98 \%$ \\
\hline
\end{tabular}

observation that of all existing indications for treatment with dynamic pedicle stabilization applied by our group, the patients with the best results were those who underwent surgery for degenerative spondylolisthesis. Our observation was proven in this study; degenerative spondylolisthesis without spondylolysis has an excellent indication for treatment with use of the dynamic pedicle system via the posterior approach. Unlike other published studies, our complication rate was low, perhaps due to the choice of the type of condition to be treated, knowledge of the technique with the preservation of all posterior elements, treatment at just one level, and also the small bias of the group. Thus as an initial study, we can demonstrate these data, and further studies will arise with comparison of treated groups such as: different degenerative pathologies and the inclusion of more than one level.

\section{CONCLUSION}

Posterior dynamic pedicle fixation with use of the Dynesys system proved to be a good option for treating degenerative spondylolisthesis without low grade spondylolysis, with satisfactory clinical and radiographic results associated with minimum complication rates.

All authors declare no potential conflict of interest concerning this article.

\section{REFERENCES}

1. Schlegel JD, Smith JA, Schleusener RL. Lumbar motion segment pathology adja- cent to thoracolumbar, lumbar, and lumbosacral fusions. Spine (Phila Pa 1976). 1996;21(8):970-81.

2. Aota $Y$, Kumano K, Hirabayashi S. Postfusion instability at the adjacent segments after rigid pedicle screw fixation for degenerative lumbar spinal disorders. J Spinal Disord. 1995:8(6):464-73.

3. Etebar S, Cahill DW. Risk factors for adjacent-segment failure following lumbar fixation with rigid instrumentation for degenerative instability. J Neurosurg. 1999:90(2 Suppl):163-9.

4. Bertagnoli R, Tropiano P, Zigler J, Karg A, Voigt S. Hybrid constructs. Orthop Clin N Am. 2005;36(3):379-88

5. Stoll TM, Dubois G, Schwarzenbach $\mathrm{O}$. The dynamic neutralization system for the spine: a multi-center study of a novel non-fusion system. Eur Spine J. 2002: 11(Suppl 2):170-8.

6. Dubois G, de Germay B, Schaerer NS, Fennema P. Dynamic neutralization a new concept for restabilization of the spine. In: Szpalski M, Gunzburg R, Pope MH, editors. Lumbar segmental instability. Philadelphia: Lippincott Williams \&Wilkins; 1999. p. 233-40.

7. Kirkaldy-Willis WH, Farfan HF. Instability of the lumbar spine. Clin Orthop Relat Res. 1982;(165):110-23
8. Sengupta DK. Dynamic stabilization devices in the treatment of low back pain. Neurol Índia. 2005:53(4):466-74.

9. Schnake KJ, Schaeren S, Jeanneret B. Dynamic stabilization in addition to decompression for lumbar spinal estenosis with degenerative spondilolisthesis. Spine (Phila Pa 1976). 2006:31(4):442-9.

10. Mulholland RC, Sengupta DK. Rationale, principles and experimental evaluation of the concept of soft stabilization. Euro Spine J. 2002;11 (Suppl 2):S198-205.

11. Welch WC, Cheng BC, Awad TE, Davis R, Maxwell JH, Delamarter R, et al. Clinical outcomes of the Dynesys dynamic neutralization system: 1-year preliminary results. Neurosurg Focus. 2007;22(1):E8.

12. Nockels RP. Dynamic stabilization in the surgical management of painful lumbar spinal disorders. Spine (Phila Pa 1976). 2005;30(16 Suppl):S68-72.

13. Ghiselli G, Wang JC, Bhatia NN, Hsu WK, Dawson EG. Adjacent segment degeneration in the lumbar spine. J Bone Joint Surg Am. 2004;86(7):1497-503.

14. Graf H. Lumbar instability: surgical treatment without fusion. Rachis. 1992: (412):123-37.

15. Rigby MC, Selmon GP, Foy MA, Fogg AJ. Graf ligament stabilisation: midtolong-term follow-up. Eur Spine J. 2001;10(3):234-6. 